\title{
Glucose inhibits glucagon secretion by a direct effect on mouse pancreatic alpha cells
}

\author{
E. Vieira • A. Salehi • E. Gylfe
}

Received: 14 July 2006 / Accepted: 2 October 2006 / Published online: 29 November 2006

(C) Springer-Verlag 2006

\begin{abstract}
Aims/hypothesis The mechanisms by which glucose regulates glucagon release are poorly understood. The present study aimed to clarify the direct effects of glucose on the glucagon-releasing alpha cells and those effects mediated by paracrine islet factors.

Materials and methods Glucagon, insulin and somatostatin release were measured from incubated mouse pancreatic islets and the cytoplasmic $\mathrm{Ca}^{2+}$ concentration $\left(\left[\mathrm{Ca}^{2+}\right]_{\mathrm{i}}\right)$ recorded in isolated mouse alpha cells.

Results Glucose inhibited glucagon release with maximal effect at $7 \mathrm{mmol} / \mathrm{l}$. Since this concentration corresponded to threshold stimulation of insulin secretion, it is unlikely that inhibition of glucagon secretion is mediated by beta cell factors. Although somatostatin secretion data seemed consistent with a role of this hormone in glucose-inhibited glucagon release, a somatostatin receptor type 2 antagonist stimulated glucagon release without diminishing the inhibitory effect of glucose. In islets exposed to tolbutamide plus $8 \mathrm{mmol} / \mathrm{l} \mathrm{K}^{+}$, glucose inhibited glucagon secretion without stimulating the release of insulin and somatostatin, indicating a direct inhibitory effect on the alpha cells that was independent of ATP-sensitive $\mathrm{K}^{+}$channels. Glucose lowered $\left[\mathrm{Ca}^{2+}\right]_{i}$ of individual alpha cells independently of somatostatin and beta cell factors (insulin, $\mathrm{Zn}^{2+}$ and $\gamma$ aminobutyric acid). Glucose suppression of glucagon release was prevented by inhibitors of the sarco(endo)plasmic
\end{abstract}

E. Vieira $\cdot$ E. Gylfe $(\bowtie)$

Department of Medical Cell Biology, Uppsala University,

BMC Box 571, SE-751 23 Uppsala, Sweden

e-mail: erik.gylfe@mcb.uu.se

\section{A. Salehi}

Department of Clinical Science, Lund University,

Clinical Research Center, Malmö University Hospital,

SE-205 02 Malmö, Sweden reticulum $\mathrm{Ca}^{2+}$-ATPase, which abolished the $\left[\mathrm{Ca}^{2+}\right]_{i}$-lowering effect of glucose on isolated alpha cells.

Conclusions/interpretation Beta cell factors or somatostatin do not seem to mediate glucose inhibition of glucagon secretion. We instead propose that glucose has a direct inhibitory effect on mouse alpha cells by suppressing a depolarising $\mathrm{Ca}^{2+}$ store-operated current.

Keywords Calcium signalling · Glucagon · Insulin secretion · Signal transduction · Somatostatin (SRIF)

\author{
Abbreviations \\ $\left[\mathrm{Ca}^{2+}\right]_{\mathrm{i}}$ cytoplasmic $\mathrm{Ca}^{2+}$ concentration \\ CPA cyclopiazonic acid \\ GABA $\gamma$-aminobutyric acid \\ $\mathrm{K}_{\text {ATP }} \quad$ ATP-sensitive $\mathrm{K}^{+}$ \\ PTX pertussis toxin \\ SERCA sarco(endo)plasmic reticulum $\mathrm{Ca}^{2+}$ ATPase \\ SSTR-2 somatostatin receptor type 2
}

\section{Introduction}

Diabetes mellitus is a disease with inappropriate secretion of blood glucose-lowering insulin. Failure of glucose to suppress the release of glucose-elevating glucagon aggravates hyperglycaemia in diabetic patients [1] and further glucose elevation has even been found to stimulate glucagon release [2-4]. Studying mouse pancreatic islets and hamster glucagon-releasing cells, we recently found that this effect may involve paradoxical stimulation of glucagon secretion by high concentrations of glucose [5]. The most important physiological role of the pancreatic alpha cell is the release of glucose-elevating glucagon in 
response to hypoglycaemia [6]. This glucose counterregulation is also impaired in diabetes, and hypoglycaemia is a significant cause of death in insulin-treated patients [7]. Understanding how glucagon secretion is regulated may lead to new strategies for improved blood glucose control in diabetes.

Insulin secretion from the pancreatic beta cell has been extensively studied. Much less is known about the stimulussecretion coupling of the glucagon-releasing pancreatic alpha cell. Fundamentally different theories about glucose regulation of glucagon secretion have emerged, which can be classified in three not mutually exclusive categories. One involves direct effects of glucose on the alpha cell [8-17]. Another is based on an indirect action mediated by release of insulin [17-22], $\gamma$-aminobutyric acid (GABA) [22-24], $\mathrm{Zn}^{2+}$ $[25,26]$ or somatostatin $[18,27]$. A third predicts that glucose sensing occurs in the hypothalamus with altered neural signalling to alpha cells [28].

Alternative mechanisms have been suggested to explain direct glucose inhibition of the alpha cells. We proposed earlier that glucose lowers cytoplasmic $\mathrm{Ca}^{2+}$ concentration $\left(\left[\mathrm{Ca}^{2+}\right]_{\mathrm{i}}\right)$ and inhibits glucagon secretion by stimulating $\mathrm{Ca}^{2+}$ sequestration in the endoplasmic reticulum [10]. This hypothesis was recently extended, showing that $\mathrm{Ca}^{2+}$ filling of the endoplasmic reticulum inhibits a depolarising storeoperated current that may control voltage-dependent $\mathrm{Ca}^{2+}$ influx and glucagon release [15]. Another proposal involves glucose control of the membrane potential via stimulation of electrogenic sodium-potassium counter transport [11]. The two latter alternatives are consistent with glucose shutting off voltage-dependent $\mathrm{Ca}^{2+}$ entry and glucagon release by hyperpolarising the alpha cell $[12,14,15]$. Paradoxically, it has also been suggested that glucose inhibits glucagon release by depolarising the alpha cells $[13,16]$. According to this theory, depolarisation by glucose-induced closure of the ATP-sensitive $\mathrm{K}^{+}\left(\mathrm{K}_{\text {ATP }}\right)$ channels inactivates the $\mathrm{Na}^{+}$ channels required for action potential firing and voltagedependent $\mathrm{Ca}^{2+}$ entry.

The present study evaluated different hypotheses for the regulation of glucagon secretion by recording $\left[\mathrm{Ca}^{2+}\right]_{\mathrm{i}}$ in isolated mouse alpha cells and by parallel measurements of glucagon, insulin and somatostatin secretion from pancreatic islets. Beta cell factors or somatostatin do not seem to mediate glucose inhibition of glucagon secretion. The results are instead consistent with direct glucose inhibition of mouse alpha cells by suppression of a depolarising $\mathrm{Ca}^{2+}$ store-operated current.

\section{Materials and methods}

Materials Reagents of analytical grade and deionised water were used. Collagenase was obtained from Boehringer
Mannheim (Mannheim, Germany) and trypsin, penicillin, streptomycin, gentamicin and the $\mathrm{Ca}^{2+}$ indicator fura-2 acetoxymethyl ester from Invitrogen (Carlsbad, CA, USA). Gibco (Paisley, Scotland, UK) supplied RPMI 1640, Dulbecco's modified essential medium and fetal calf serum. Poly-L-lysine, pertussis toxin (PTX), BSA, GABA, HEPES, thapsigargin, wortmannin, adrenaline and nifedipine were supplied by Sigma Chemical (St Louis, MO, USA). Cyclopiazonic acid (CPA) was from Calbiochem (La Jolla, CA, USA), and $\omega$-conotoxin from Alomone Labs (Jerusalem, Israel). Tolbutamide and the somatostatin receptor type 2 (SSTR-2) antagonist PRL-2903 were kind gifts from Hoechst Marion Roussel (Stockholm, Sweden) and D. H. Coy (Tulane University, New Orleans, LA, USA), respectively.

Preparation of pancreatic islets and cells $\mathrm{C} 57 \mathrm{BL} / 6$ mice (Taconic M\&B, Ry, Denmark) were used. Local ethics committees approved the experimental procedures. The animals were killed by decapitation under anaesthesia with $\mathrm{CO}_{2}$. The peritoneal cavity was opened and collagenase solution was injected into the bile-pancreatic duct to expand the pancreas (glucagon secretion experiments). Pancreas was excised and cut into small pieces, which were digested with collagenase to obtain free islets of Langerhans. The lower duodenal part of the pancreas was rejected to avoid islets with pancreatic polypeptide-producing cells [29]. The freshly isolated islets were either used for studies of glucagon secretion or dissociated into free cells. Free cells were obtained by incubating the islets for $4 \mathrm{~min}$ at $37^{\circ} \mathrm{C}$ in $\mathrm{Ca}^{2+}$-deficient medium containing $0.5 \mathrm{mmol} / 1$ EDTA and $0.05 \%$ trypsin followed by brief shaking. The cells were suspended in RPMI 1640 medium with $5.5 \mathrm{mmol} / 1$ glucose supplemented with $10 \%$ fetal calf serum, $100 \mathrm{IU} / \mathrm{ml}$ penicillin, $100 \mu \mathrm{g} / \mathrm{ml}$ streptomycin and $30 \mu \mathrm{g} / \mathrm{ml}$ gentamicin. Small samples of this suspension $(15 \mu \mathrm{l})$ were applied to the centres of poly-L-lysine-coated circular $25 \mathrm{~mm}$ cover slips. The cover slips were then kept for $60 \mathrm{~min}$ in a culture incubator at $37^{\circ} \mathrm{C}$ with a humidified atmosphere of $5 \% \mathrm{CO}_{2}$ to allow cells to settle and begin attachment. More medium was then added and the cells were cultured for 1 to 3 days. In some experiments $100 \mathrm{ng} / \mathrm{ml}$ PTX was present during the last 20 to $24 \mathrm{~h}$.

Loading with indicator Loading of cells with the $\mathrm{Ca}^{2+}$ indicator fura-2 was performed during $40 \mathrm{~min}$ incubation at $37^{\circ} \mathrm{C}$ in a buffer containing $0.5 \mathrm{mg} / \mathrm{ml}$ BSA, $125 \mathrm{mmol} / 1 \mathrm{NaCl}, 4.8 \mathrm{mmol} / \mathrm{l} \mathrm{KCl}, 1.2 \mathrm{mmol} / \mathrm{l} \mathrm{MgCl}_{2}$, $1.28 \mathrm{mmol} / 1 \mathrm{CaCl}_{2}, 3 \mathrm{mmol} / \mathrm{l}$ glucose, $1 \mu \mathrm{mol} / \mathrm{l}$ fura-2 acetoxymethyl ester and $25 \mathrm{mmol} / \mathrm{l}$ HEPES with $\mathrm{pH}$ adjusted to 7.4 with $\sim 13 \mathrm{mmol} / 1 \mathrm{NaOH}$. When the effects of higher concentrations of $\mathrm{KCl}$ were tested, osmotic compensation was made by reducing $\mathrm{NaCl}$. The cover slips with the 
attached cells were used as exchangeable bottoms of an open chamber. The chamber volume was $0.16 \mathrm{ml}$ and the cells were superfused with a medium at a rate of $1 \mathrm{ml} / \mathrm{min}$. Thapsigargin was added directly to the superfusion chamber. The superfusion flow was then interrupted for 2 to $3 \mathrm{~min}$ to ascertain an effect of the drug.

Measurements of $\left[\mathrm{Ca}^{2+}\right]_{i}$ by digital imaging fluorometry The superfusion chamber was placed on the stage of an inverted Nikon Diaphot microscope equipped with an epifluorescence illuminator and a $\times 40$ oil immersion fluorescence objective (Tekno Optik, Huddinge, Sweden). The chamber holder and the objective were maintained at $37^{\circ} \mathrm{C}$. A $150-\mathrm{W}$ xenon arc lamp and an Optoscan monochromator (Cairn Research, Faversham, UK) provided excitation light at 340 and $380 \mathrm{~nm}$ and emission was measured at $>515 \mathrm{~nm}$ by an intensified CCD camera (Extended ISIS-M; Photonic Science, Robertsbridge, UK). The Metafluor software (Universal Imaging, Downingtown, PA, USA) controlled the monochromator acquiring fluorescence images of 30 accumulated frames at 340 and $380 \mathrm{~nm}$ every $4 \mathrm{~s}$. $\left[\mathrm{Ca}^{2+}\right]_{\mathrm{i}}$ images were calculated from 340:380 $\mathrm{nm}$ ratio images as previously described [15].

Paracrine influence Image fields with high cell density (average 13 cells per field) were selected to obtain data from more than one alpha cell. Few cells were found in the periphery and the average cell density was considerably smaller. Since the chamber medium was exchanged six times per min, it is obvious that the concentrations of paracrine factors released from beta cells and delta cells were much lower than those reached in the narrow intercellular space of islets when measuring secretion in batch incubations. Maximal stimulation of insulin secretion with $20 \mathrm{mmol} / \mathrm{l}$ glucose raised the insulin content of the medium to $<1 \mathrm{pmol} / 1$ as determined by ultrasensitive ELISA [30] in ten experiments. Pretreatment with PTX, which blocks the inhibitory effect of somatostatin [31], and exposure to $0.1 \mu \mathrm{mol} / 1$ of the phosphatidylinositol-3 kinase inhibitor wortmannin, which inhibits insulin signalling [17], were used to clarify whether the effects of glucose on $\left[\mathrm{Ca}^{2+}\right]_{\mathrm{i}}$ could be explained by paracrine influence from delta and beta cells on the cover slip.

Identification of alpha cells The alpha cells were initially selected by their small size and $\left[\mathrm{Ca}^{2+}\right]_{\mathrm{i}}$ response to adrenaline [15, 32], which is not shared by beta [15] and delta cells [33]. Only alpha cells confirmed by positive glucagon immunostaining were included in the analyses [15].

Glucagon, insulin and somatostatin secretion Batches of eight to 12 islets were pre-incubated for $30 \mathrm{~min}$ at $37^{\circ} \mathrm{C}$ in
$1 \mathrm{ml}$ of Krebs-Ringer buffer (pH 7.4) supplemented with $10 \mathrm{mmol} / 1 \mathrm{HEPES}, 0.1 \% \mathrm{BSA}$ and $1 \mathrm{mmol} / 1$ glucose. Each incubation vial was gassed with $95 \% \mathrm{O}_{2}$ and $5 \% \mathrm{CO}_{2}$ to obtain constant $\mathrm{pH}$ and oxygenation. The islets were then incubated for $1 \mathrm{~h}$ at $37^{\circ} \mathrm{C}$ in a Krebs-Ringer buffer supplemented with different glucose concentrations, $500 \mu \mathrm{mol} / \mathrm{l}$ tolbutamide, 4.8 or $8 \mathrm{mmol} / 1 \mathrm{~K}^{+}$and $50 \mu \mathrm{mol} / 1$ CPA (as stated in figure legends). Aliquots of the medium were frozen pending the radioimmunoassays [34, 35].

Statistical analysis Dose-response relationships for the effect of glucose on hormone secretion were analysed with ANOVA and paired Student's $t$ tests. The effects of other additions on the glucose dose-response relationships were evaluated with unpaired Student's $t$ tests. When the glucose concentrations did not match exactly, test data were compared with interpolated control data. The reaction patterns in individual alpha cells were considerably heterogeneous. Even alpha cells on the same cover slip often reacted differently to the same experimental challenge. Due to the qualitative differences in cellular responses, the results have been presented as proportions of cells reacting in different ways. Analyses of the proportion of cells with a certain response were made with two-tailed Fisher's exact test or $\chi^{2}$ test with Yates' correction. Wilcoxon's signed rank test was used to analyse the effect of different glucose concentrations on $\left[\mathrm{Ca}^{2+}\right]_{\mathrm{i}}$. All calculations were made by SigmaStat software (Systat Software, Erkrath, Germany).

\section{Results}

Relationship between glucose-regulated glucagon, insulin and somatostatin secretion Since glucose control of glucagon secretion has been suggested to involve paracrine release of insulin [17-22], GABA [22-24] and $\mathrm{Zn}^{2+}$ [25, 26] from the beta cells, and somatostatin from the delta cells $[18,27]$, we studied how the glucose concentration affected the release of hormones from mouse islets. Glucagon secretion was inhibited by glucose in the 4 to $20 \mathrm{mmol} / \mathrm{l}$ range with maximal effect at $7 \mathrm{mmol} / \mathrm{l}$ (Fig. 1a). The parallel measurements of insulin showed threshold stimulation at $7 \mathrm{mmol} / \mathrm{l}$ glucose with maximal secretion at $20 \mathrm{mmol} / \mathrm{l}$ (Fig. 1b). Consequently, it is unlikely that insulin or $\mathrm{Zn}^{2+}$ co-secreted from the same beta cell granules or the similarly regulated release of GABA from beta cell microvesicles [36] contribute to inhibition of glucagon secretion by up to $7 \mathrm{mmol} / \mathrm{l}$ glucose. Although somatostatin secretion was dose-dependently stimulated by 4 to $20 \mathrm{mmol} / \mathrm{l}$ glucose (Fig. 1c), this hormone does not seem to mediate glucose inhibition of glucagon release. Blocking the dominating 

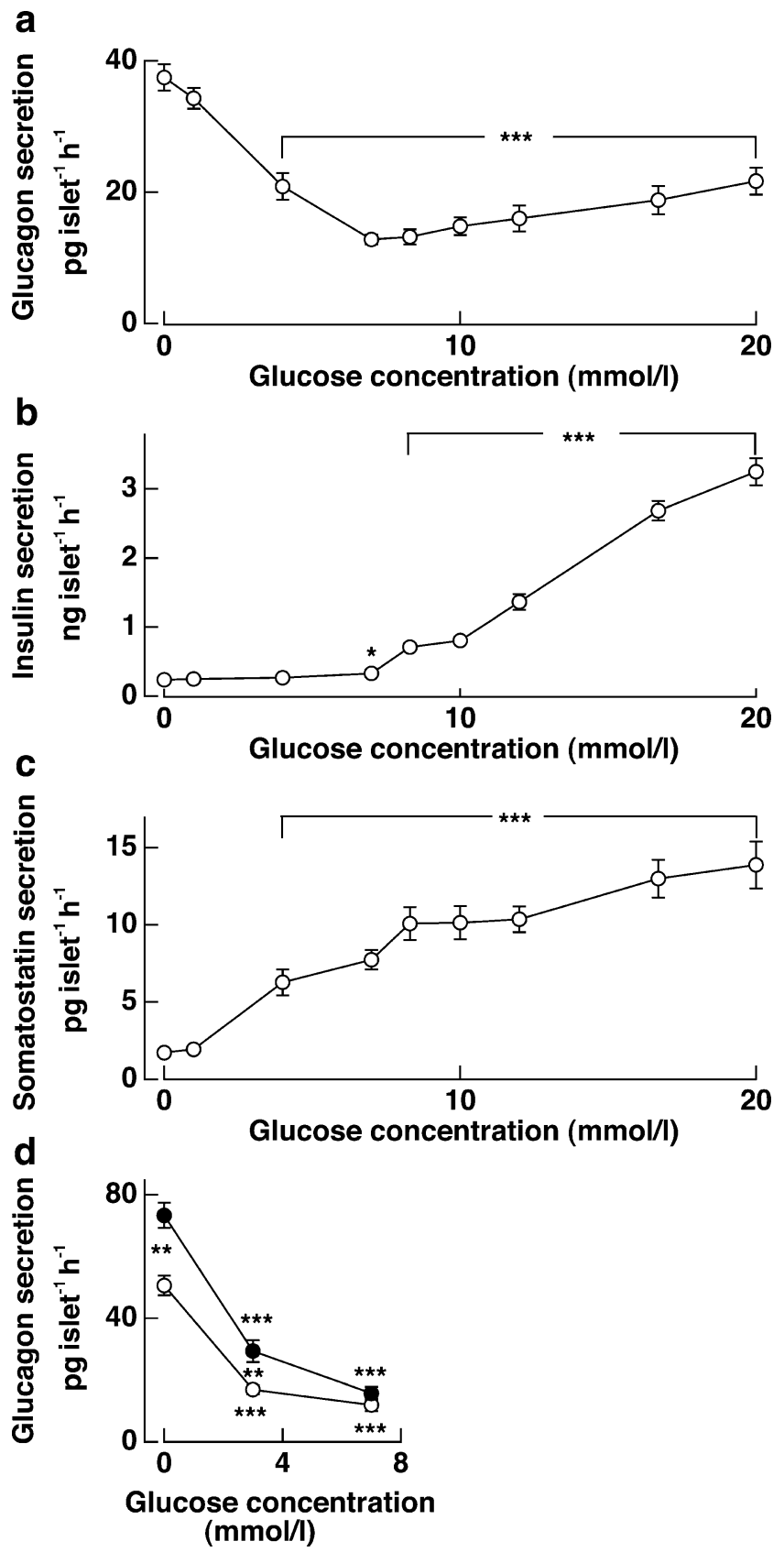

Fig. 1 Glucose dependence of glucagon, insulin and somatostatin secretion from mouse pancreatic islets. Glucagon (a), insulin (b) and somatostatin (c) secretion were measured after 60 min incubation in the presence of 0 to $20 \mathrm{mmol} / 1$ glucose (open circles, solid lines). The effect (d) of $5 \mu \mathrm{mol} / 1$ of the SSTR-2 antagonist PRL-2903 on glucagon secretion (filled circles, solid lines) was also compared with control data (open circles, solid lines) in the presence of 0 to $7 \mathrm{mmol} / \mathrm{l}$ glucose. Data are presented as means \pm SEM of six to eight experiments. Asterisk: $p<0.05$, triple asterisks: $p<0.001$ for the effect of glucose compared with the lowest concentration tested $(0 \mathrm{mmol} / \mathrm{l})$. Double asterisks: $p<0.01$ for the effect of PRL-2903 compared with control. Brackets indicate observations with identical significance levels

somatostatin receptor subtype SSTR-2 in alpha cells with PRL-2903 [27] thus stimulated glucagon secretion in low glucose without affecting maximally inhibited secretion in $7 \mathrm{mmol} / \mathrm{l}$ sugar (Fig. 1d).
Closure of $K_{A T P}$ channels activates $\mathrm{Ca}^{2+}$ influx through L-type channels $\mathrm{It}$ is well established that closure of $\mathrm{K}_{\mathrm{ATP}}$ channels, with resulting depolarisation and rise of $\left[\mathrm{Ca}^{2+}\right]_{\mathrm{i}}$, underlies glucose stimulation of insulin [37] and somatostatin $[33,38]$ secretion. By analogy it is clear that glucose inhibition of glucagon release is associated with lowering of $\left[\mathrm{Ca}^{2+}\right]_{i}[5,10,13,15,16]$. According to one hypothesis, the latter effect is paradoxically due to closure of $\mathrm{K}_{\mathrm{ATP}}$ channels with depolarisation leading to voltage-dependent inactivation of $\mathrm{Na}^{+}$channels involved in the action potential firing $[13,16]$. We therefore tested how $\mathrm{K}_{\text {АTP }}$ channel closure affected $\left[\mathrm{Ca}^{2+}\right]_{\mathrm{i}}$ in individual mouse alpha cells. Among alpha cells with spontaneous $\left[\mathrm{Ca}^{2+}\right]_{\mathrm{i}}$ activity in $1 \mathrm{mmol} / 1$ glucose, $80 \%$ reacted to $500 \mu \mathrm{mol} / 1$ of the $\mathrm{K}_{\mathrm{ATP}}$ channel inhibitor tolbutamide by elevation of $\left[\mathrm{Ca}^{2+}\right]_{\mathrm{i}}$ (Fig. 2a,c). However, in cells without spontaneous activity, the fraction of cells responding to tolbutamide was only $21 \%$. These observations suggested that $\mathrm{K}_{\text {ATP }}$ channel closure tended to stimulate rather than inhibit the alpha cells, and that tolbutamide depolarisation was not sufficient to open voltage-gated $\mathrm{Ca}^{2+}$ channels unless the cells were already depolarised to some extent. This alternative was further investigated after slightly depolarising the alpha cells by raising the $\mathrm{K}^{+}$concentration from 4.8 to $8 \mathrm{mmol} / \mathrm{l}$. Such depolarisation caused a $\left[\mathrm{Ca}^{2+}\right]_{\mathrm{i}}$ response in $11 \%$ of the silent alpha cells and in $67 \%$ of those with spontaneous $\left[\mathrm{Ca}^{2+}\right]_{i}$ activity (Fig. 2b,c). Indeed, with subsequent addition of $500 \mu \mathrm{mol} / 1$ tolbutamide, all alpha cells responded with an increase of $\left[\mathrm{Ca}^{2+}\right]_{\mathrm{i}}$. Figure $2 \mathrm{~b}$ shows an alpha cell that did not react with elevation of $\left[\mathrm{Ca}^{2+}\right]_{i}$ when exposed to either tolbutamide or $8 \mathrm{mmol} / 1 \mathrm{~K}^{+}$individually, but which manifested a clear response when exposed to a combination of both stimuli.

Voltage-dependent $\mathrm{Ca}^{2+}$ influx into alpha cells has been attributed to opening of both L- $[13,15,20,39,40]$ and Ntype channels [31]. We therefore tested the identity of the channels causing depolarisation-dependent elevation of $\left[\mathrm{Ca}^{2+}\right]_{\mathrm{i}}$. Whereas the N-type $\mathrm{Ca}^{2+}$ channel blocker $\omega$ conotoxin did not affect the elevation/oscillations of $\left[\mathrm{Ca}^{2+}\right]_{\mathrm{i}}$ induced by tolbutamide $/ 8 \mathrm{mmol} / 1 \mathrm{~K}^{+}$in any of 12 alpha cells, the L-type $\mathrm{Ca}^{2+}$ channel blocker nifedipine abolished the $\left[\mathrm{Ca}^{2+}\right]_{\mathrm{i}}$ response in all 12 alpha cells $(p<0.001$; Fig. 3$)$. Taken together, these data indicated that the $\mathrm{K}_{\text {ATP }}$ channels were functionally active in mouse alpha cells and that their closure tended to activate $\mathrm{Ca}^{2+}$ influx through L-type channels [31]. In subsequent experiments the combination tolbutamide plus $8 \mathrm{mmol} / 1 \mathrm{~K}^{+}$was used to study $\mathrm{K}_{\text {ATP }}$ channel-independent effects of glucose.

Glucose inhibits glucagon secretion independently of $K_{A T P}$ channels, beta cell factors and somatostatin Activation of $\mathrm{K}_{\text {ATP }}$ channels with diazoxide hyperpolarises mouse alpha cells [15] and inhibits glucagon release from mouse islets, 

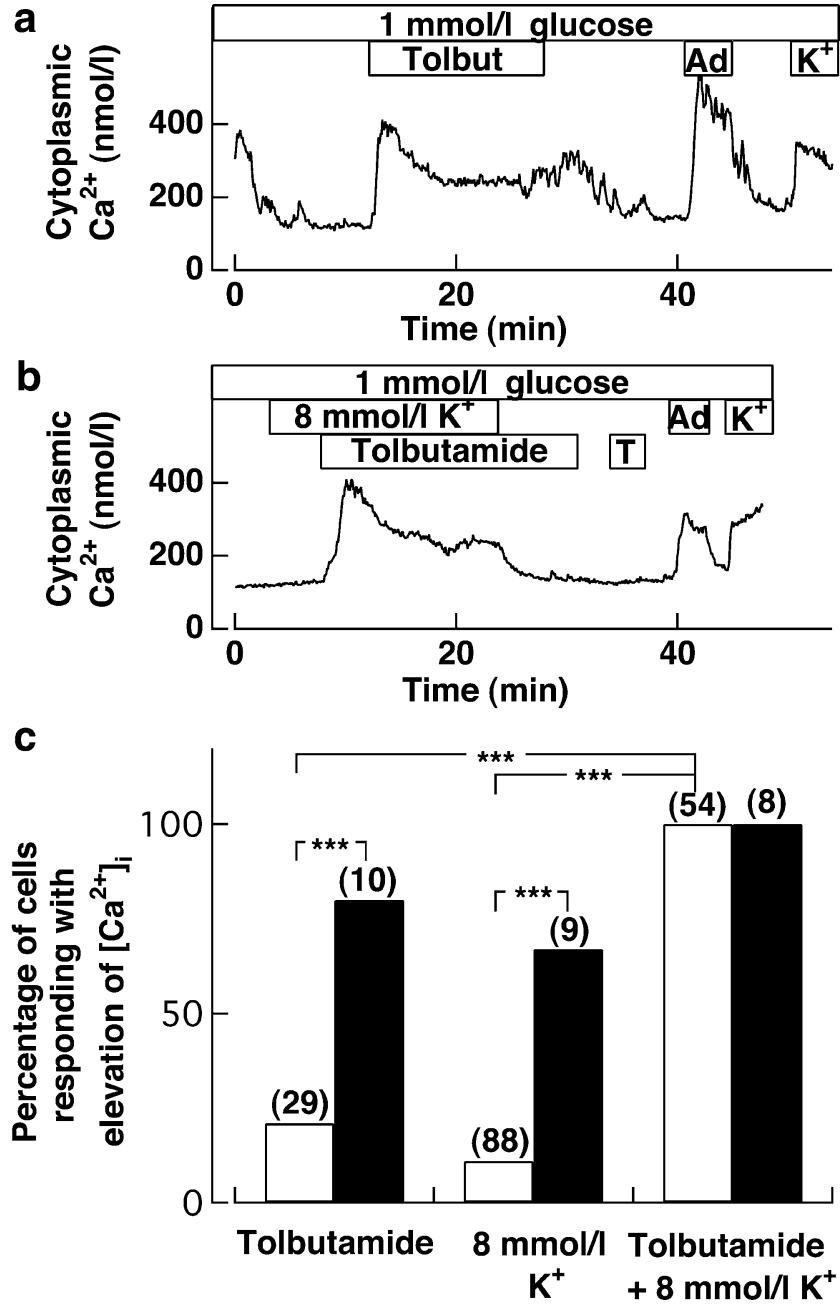

Fig. 2 Effects of tolbutamide and $8 \mathrm{mmol} / 1 \mathrm{~K}^{+}$on $\left[\mathrm{Ca}^{2+}\right]_{\mathrm{i}}$ of alpha cells exposed to $1 \mathrm{mmol} / \mathrm{l}$ glucose. The cells were loaded with the $\mathrm{Ca}^{2+}$ indicator fura-2. Traces from individual alpha cells $(\mathbf{a}, \mathbf{b})$ and percentages of cells responding to tolbutamide and $8 \mathrm{mmol} / \mathrm{l} \mathrm{K} \mathrm{K}^{+}$alone or in combination (c) are shown. Tolbutamide (Tolbut, T; $500 \mu \mathrm{mol} / 1$ ), adrenaline (Ad; $5 \mu \mathrm{mol} / \mathrm{l}$ ) and $8 \mathrm{mmol} / \mathrm{l} \mathrm{K} \mathrm{K}^{+}$were present as indicated. At the end of the experiment $(\mathbf{a}, \mathbf{b})$, the $\mathrm{K}^{+}$concentration was raised to $30 \mathrm{mmol} / \mathrm{l}\left(\mathrm{K}^{+}\right)$. c Responses of initially silent alpha cell (open bars) and those with spontaneous $\left[\mathrm{Ca}^{2+}\right]_{\mathrm{i}}$ activity in $1 \mathrm{mmol} / \mathrm{l}$ glucose (filled bars). Statistical evaluation was made by Fisher exact test or $\chi^{2}$ test with Yates' correction on the proportions of cells with different responses. Numbers of cells are given in parentheses. Triple asterisks: $p<0.001$

but does not prevent additional inhibition by glucose [5]. We now observed that depolarisation with $500 \mu \mathrm{mol} / \mathrm{l}$ tolbutamide plus $8 \mathrm{mmol} / 1 \mathrm{~K}^{+}$inhibited glucagon secretion by $30 \%$ at $1 \mathrm{mmol} / 1$ glucose without affecting its release at other sugar concentrations (Fig. 4a). Insulin secretion was slightly stimulated by tolbutamide $/ 8 \mathrm{mmol} / 1 \mathrm{~K}^{+}$at all glucose concentrations (Fig. 4b). Somatostatin release was stimulated fourfold at $1 \mathrm{mmol} / \mathrm{l}$ glucose and by $65 \%$ at $20 \mathrm{mmol} / \mathrm{l}$, but no effect of tolbutamide $/ 8 \mathrm{mmol} / 1 \mathrm{~K}^{+}$was seen at 3 to $8 \mathrm{mmol} / \mathrm{l}$ glucose (Fig. 4c). The marked stimulation of somatostatin in $1 \mathrm{mmol} / \mathrm{l}$ glucose probably explains the associated inhibition of glucagon release (Fig. 4a). The presence of tolbutamide $/ 8 \mathrm{mmol} / 1 \mathrm{~K}^{+}$did not prevent glucose inhibition of glucagon secretion in the 5 to $20 \mathrm{mmol} / \mathrm{l}$ range, indicating involvement of a mechanism independent of the $\mathrm{K}_{\text {ATP }}$ channel. Again, inhibition of glucagon secretion by the lower glucose concentrations could not be explained by release of beta cell factors, since insulin secretion remained at basal levels at 1 to $5 \mathrm{mmol} / \mathrm{l}$ glucose (Fig. 4b). Inhibition of glucagon secretion also did not correlate with stimulated release of somatostatin, which was unaffected in the 1 to $8 \mathrm{mmol} / \mathrm{l}$ glucose range and enhanced only by $20 \mathrm{mmol} / \mathrm{l}$ of the sugar (Fig. 4c). Since these data suggested that glucose has a direct effect on the alpha cells, we studied how glucose affected the $\mathrm{Ca}^{2+}$ signalling that was induced by tolbutamide $/ 8 \mathrm{mmol} / 1 \mathrm{~K}^{+}$in individual alpha cells. Figure $4 \mathrm{~d}$ shows that an increase of glucose from 0 to $10 \mathrm{mmol} / 1$ inhibited the $\left[\mathrm{Ca}^{2+}\right]_{\mathrm{i}}$ oscillations induced by tolbutamide $/ 8 \mathrm{mmol} / \mathrm{l} \mathrm{K}^{+}$in an alpha cell. In a series of similar experiments with elevation of the glucose concentration from 0 to $1,3,5,10$ or $20 \mathrm{mmol} / \mathrm{l}$, the sugar caused concentration-dependent reductions of $\left[\mathrm{Ca}^{2+}\right]_{\mathrm{i}}$ (Table 1).

It seems unlikely that paracrine factors released from beta and delta cells on the cover slips affected the measurements of $\left[\mathrm{Ca}^{2+}\right]_{i}$ in the alpha cells (see methods). Nevertheless, we tested whether insulin, GABA, $\mathrm{Zn}^{2+}$ or somatostatin might be involved in the glucose-induced lowering of $\left[\mathrm{Ca}^{2+}\right]_{i}$. Insulin has a weak tendency to inhibit spontaneous $\left[\mathrm{Ca}^{2+}\right]_{\mathrm{i}}$ signalling in mouse alpha cells [20]. However, the $\left[\mathrm{Ca}^{2+}\right]_{\mathrm{i}}$ response to $500 \mu \mathrm{mol} / 1$ tolbutamide plus $8 \mathrm{mmol} / 1 \mathrm{~K}^{+}$was unaffected by 20 and $100 \mathrm{nmol} / 1$ insulin in all of six and nine alpha cells respectively or by

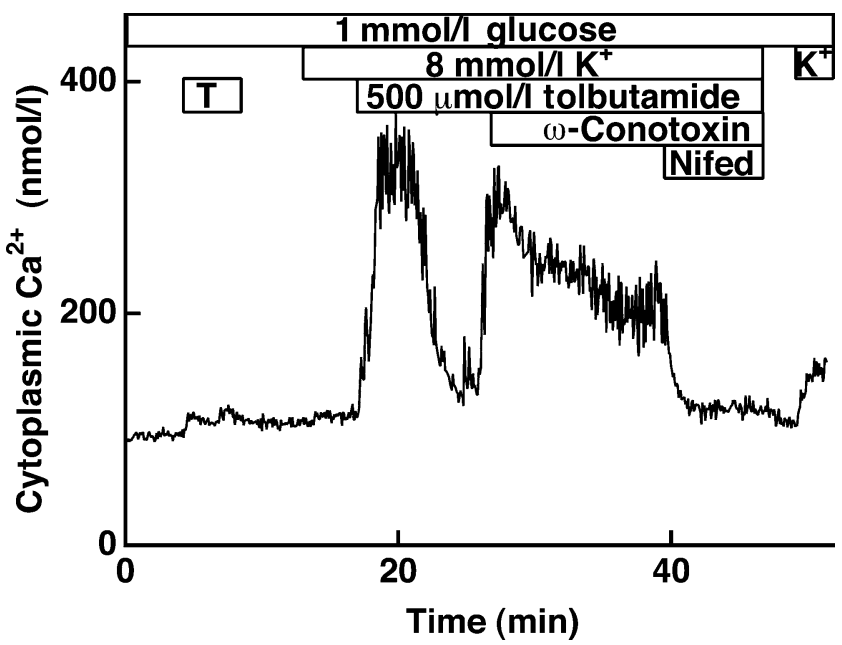

Fig. 3 Effects of $\omega$-conotoxin and nifedipine on $\left[\mathrm{Ca}^{2+}\right]_{i}$ of an alpha cell stimulated with tolbutamide plus $8 \mathrm{mmol} / 1 \mathrm{~K}^{+}$. The cells were loaded with the $\mathrm{Ca}^{2+}$ indicator fura-2. Tolbutamide (T, $\left.500 \mu \mathrm{mol} / \mathrm{l}\right)$, $\omega$-conotoxin $(0.1 \mu \mathrm{mol} / \mathrm{l})$, nifedipine (Nifed; $10 \mu \mathrm{mol} / \mathrm{l})$ and $8 \mathrm{mmol} / 1 \mathrm{~K}^{+}$were then present as indicated. At the end of the experiment, the $\mathrm{K}^{+}$concentration was raised to $30 \mathrm{mmol} / \mathrm{l}\left(\mathrm{K}^{+}\right)$ 

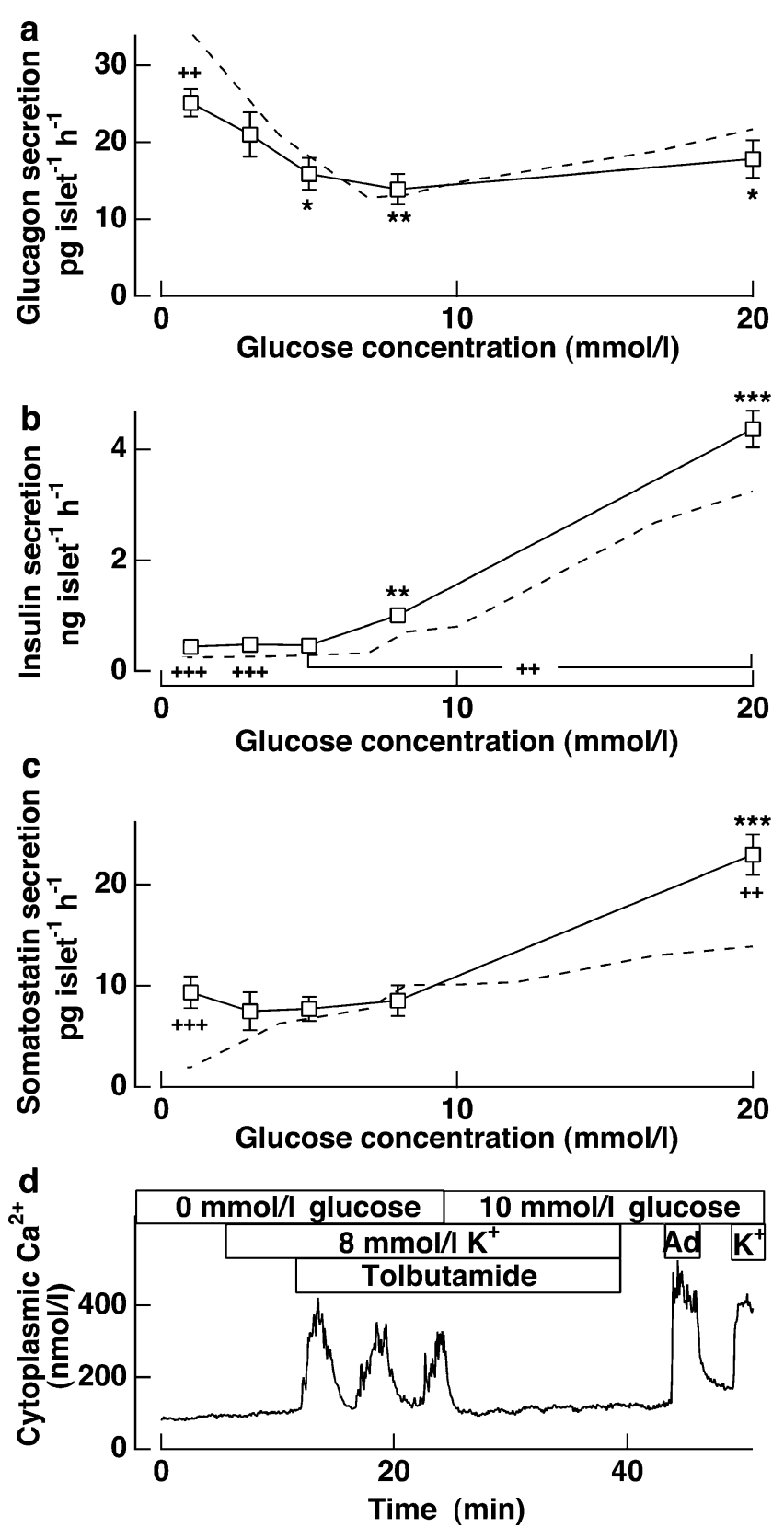

Fig. 4 Glucose dependence of glucagon, insulin and somatostatin secretion from mouse pancreatic islets with closed $\mathrm{K}_{\mathrm{ATP}}$ channels and effect of glucose on $\left[\mathrm{Ca}^{2+}\right]_{\mathrm{i}}$ of an alpha cell under such conditions. Glucagon (a), insulin (b) and somatostatin (c) secretion were measured after $60 \mathrm{~min}$ incubation in the presence of $500 \mu \mathrm{mol} / \mathrm{l}$ tolbutamide plus $8 \mathrm{mmol} / 1 \mathrm{~K}^{+}$and 1 to $20 \mathrm{mmol} / \mathrm{l}$ glucose (open squares, solid lines). Control secretion data in 1 to $20 \mathrm{mmol} / \mathrm{l}$ glucose alone from Fig. 1 are included for comparison (dashed lines). Data are presented as means \pm SEM of six experiments. Asterisks: $p<0.05$, double asterisks: $p<0.01$, triple asterisks: $p<0.001$ for the effect of glucose compared with the lowest concentration tested $(1 \mathrm{mmol} / \mathrm{l})$. Double plus signs: $p<0.01$, triple plus signs: $p<0.001$ for the effect of $500 \mu \mathrm{mol} / 1$ tolbutamide plus $8 \mathrm{mmol} / 1 \mathrm{~K}^{+}$compared with control. d $\left[\mathrm{Ca}^{2+}\right]_{\mathrm{i}}$ was measured in an alpha cell loaded with the $\mathrm{Ca}^{2+}$ indicator fura-2. Glucose $(0$ or $10 \mathrm{mmol} / \mathrm{l})$, tolbutamide $(500 \mu \mathrm{mol} / \mathrm{l}), 8 \mathrm{mmol} / \mathrm{l} \mathrm{K}$, adrenaline (Ad, $5 \mu \mathrm{mol} / \mathrm{l})$ were present as indicated. At the end of the experiment, the $\mathrm{K}^{+}$ concentration was raised to $30 \mathrm{mmol} / \mathrm{l}\left(\mathrm{K}^{+}\right)$ blocking insulin signalling with wortmannin in nine alpha cells (not shown). In addition, $1 \mathrm{mmol} / \mathrm{l}$ GABA failed to affect $\left[\mathrm{Ca}^{2+}\right]_{i}$ in all of five alpha cells exposed to $500 \mu \mathrm{mol} / 1$ tolbutamide plus $8 \mathrm{mmol} / 1 \mathrm{~K}^{+}$(data not shown). Inconsistent with an inhibitory effect of $\mathrm{Zn}^{2+}$ on glucagon secretion from rat islets [25, 26], but supporting other $\left[\mathrm{Ca}^{2+}\right]_{\mathrm{i}}$ measurements in mouse alpha cells [17], we found that $30 \mu \mathrm{mol} / 1 \mathrm{Zn}^{2+}$ always stimulated $\left[\mathrm{Ca}^{2+}\right]_{\mathrm{i}}$ signalling (nine alpha cells, data not shown). Although somatostatin immediately inhibited the $\left[\mathrm{Ca}^{2+}\right]_{\mathrm{i}}$ response to $500 \mu \mathrm{mol} / 1$ tolbutamide plus $8 \mathrm{mmol} / \mathrm{l} \mathrm{K}^{+}$in all of six alpha cells, this inhibition was completely prevented by PTX pre-treatment in all of seven alpha cells $(p<0.001$, data not shown). However, interference with somatostatin and insulin signalling with PTX pre-treatment and wortmannin did not prevent the $\left[\mathrm{Ca}^{2+}\right]_{\mathrm{i}}$-lowering effect of $20 \mathrm{mmol} / \mathrm{l}$ glucose in any of 11 alpha cells (Table 1). Taken together the data indicated that in the presence of tolbutamide $/ 8 \mathrm{mmol} / 1 \mathrm{~K}^{+}$glucose inhibits $\left[\mathrm{Ca}^{2+}\right]_{\mathrm{i}}$ signalling by a direct effect on the alpha cells.

Activation of a $\mathrm{Ca}^{2+}$ store-operated mechanism stimulates glucagon secretion and prevents the inhibitory effect of glucose We recently demonstrated that exposure to the sarco(endo)plasmic reticulum $\mathrm{Ca}^{2+}$ ATPase (SERCA) inhibitors CPA and thapsigargin activates a store-operated cation influx resulting in alpha cell depolarisation and voltage-dependent $\left[\mathrm{Ca}^{2+}\right]_{i}$ signalling [15]. In the presence of $1 \mathrm{mmol} / 1$ glucose we now found that $50 \mu \mathrm{mol} / \mathrm{l} \mathrm{CPA}$ or $200 \mathrm{nmol} / 1$ thapsigargin raised $\left[\mathrm{Ca}^{2+}\right]_{\mathrm{i}}$ in all of ten previously silent alpha cells (data not shown). CPA was also effective in $20 \mathrm{mmol} / 1$ glucose, reversing glucose inhibition of $\left[\mathrm{Ca}^{2+}\right]_{\mathrm{i}}$ signalling stimulated by tolbutamide/ $8 \mathrm{mmol} / \mathrm{l} \mathrm{K}^{+}$in all of 12 alpha cells (Fig. 5a). Moreover, an increase of glucose from 1 to $20 \mathrm{mmol} / \mathrm{l}$ failed to reduce $\left[\mathrm{Ca}^{2+}\right]_{\mathrm{i}}$ in $74 \%$ (five of seven) of alpha cells exposed to CPA and in all of ten alpha cells exposed to thapsigargin (data not shown). Activation of the store-operated mechanism by blocking the SERCA pump with CPA stimulated glucagon secretion and prevented the inhibitory effect of glucose (Fig. 5b). In the presence of CPA there was even a slight stimulation of glucagon release by $20 \mathrm{mmol} / \mathrm{l}$ glucose. Parallel insulin measurements showed no effect of CPA on basal secretion in 0 to $5 \mathrm{mmol} / \mathrm{l}$ glucose and moderate amplification in 8 and $20 \mathrm{mmol} / \mathrm{l}$ of the sugar (Fig. $5 \mathrm{c}$ ). In the absence of glucose, CPA had no effect on somatostatin secretion, but unexpectedly diminished glucose-stimulated release of the hormone (Fig. 5d).

CPA stimulation of glucagon secretion was slightly reduced in the presence of tolbutamide $/ 8 \mathrm{mmol} / 1 \mathrm{~K}^{+}$, but glucose still failed to inhibit secretion (Fig. 6a). Insulin secretion was marginally enhanced when CPA was combined with tolbutamide $/ 8 \mathrm{mmol} / \mathrm{l} \mathrm{K}{ }^{+}$compared with CPA 
Table $1\left[\mathrm{Ca}^{2+}\right]_{\mathrm{i}}$-reducing effect of introducing different glucose concentrations on mouse alpha cells stimulated with $500 \mu \mathrm{mol} / 1$ tolbutamide plus $8 \mathrm{mmol} / 1 \mathrm{~K}^{+}$

\begin{tabular}{|c|c|c|c|c|c|c|}
\hline & \multicolumn{6}{|c|}{ Glucose concentration $(\mathrm{mmol} / \mathrm{l})$} \\
\hline & 1 & 3 & 5 & 10 & 20 & 20, PTX, Wort \\
\hline No change of $\left[\mathrm{Ca}^{2+}\right]_{\mathrm{i}}$ & $14 \%$ & $14 \%$ & $9 \%$ & $27 \%$ & $0 \%$ & $0 \%$ \\
\hline Temporary reduction of $\left[\mathrm{Ca}^{2+}\right]_{\mathrm{i}}$ & $57 \%$ & $29 \%$ & $9 \%$ & $27 \%$ & $0 \%$ & $0 \%$ \\
\hline Sustained reduction of $\left[\mathrm{Ca}^{2+}\right]_{\mathrm{i}}$ & $29 \%$ & $57 \%$ & $82 \%$ & $45 \%$ & $100 \%$ & $100 \%$ \\
\hline Number of cells & 7 & 7 & 11 & 11 & 11 & 11 \\
\hline$p$ & $<0.05$ & $<0.05$ & $<0.01$ & $<0.01$ & $<0.001$ & $<0.001$ \\
\hline
\end{tabular}

Experiments were performed as illustrated in Fig. 4d. The percentages of cells with certain responses are indicated, as well as the total numbers of cells. PTX, Wort: results for cells also treated with $100 \mathrm{ng} / \mathrm{ml}$ pertussis toxin and exposed to $0.1 \mu \mathrm{mol} / 1$ wortmannin. Statistical evaluation of the glucose effect was made by Wilcoxon signed rank test on the proportions of cells with different responses

alone, but the stimulatory effect of glucose was unaffected (Fig. 6b). CPA inhibition of somatostatin release in $5 \mathrm{mmol} / \mathrm{l}$ glucose (Fig. 5d) was unaffected by the presence of tolbutamide $/ 8 \mathrm{mmol} / 1 \mathrm{~K}^{+}$(Fig. 6c). However, tolbutamide $/ 8 \mathrm{mmol} / 1 \mathrm{~K}^{+}$completely reversed $\mathrm{CPA}$ inhibition of the somatostin secretion stimulated by 8 to $20 \mathrm{mmol} / \mathrm{l}$ glucose (Figs. 5d, 6c). The data in Figs. 5 and 6 show that activation of the store-operated mechanism abolishes glucose inhibition of glucagon secretion without preventing glucose stimulation of insulin and somatostatin secretion.

\section{Discussion}

Glucagon secretion is inhibited by lower glucose concentrations than those stimulating insulin release [41]. Our data indicated that maximal inhibition of glucagon secretion from mouse islets was obtained at the threshold for glucose stimulation of insulin release. In accordance with previous arguments [42], this finding does not favour the concept that insulin or co-secreted beta cell factors inhibit glucagon release in the 0 to $7 \mathrm{mmol} / 1$ glucose range. The observations that the SSTR-2 antagonist PRL-2903 stimulated glucagon secretion in 0 to $3 \mathrm{mmol} / \mathrm{l}$ glucose support the idea that somatostatin has a tonic inhibitory effect on alpha cells exposed to low glucose [31]. However, the failure of PRL-2903 to affect maximal inhibition of glucagon release by $7 \mathrm{mmol} / \mathrm{l}$ glucose argues against somatostatin as mediator of this inhibition. When the mouse islets were exposed to tolbutamide plus $8 \mathrm{mmol} / 1 \mathrm{~K}^{+}$in $1 \mathrm{mmol} / 1$ glucose, partial inhibition of glucagon release occurred concomitantly with a slight increase of insulin and pronounced stimulation of somatostatin secretion. Inhibition of glucagon secretion by tolbutamide alone or $\mathrm{K}^{+}$concentrations up to $16 \mathrm{mmol} / \mathrm{l}$ has previously been observed in mouse islets [16]. Based on the present data, we suggest that this inhibition is mediated by somatostatin.
In the presence of tolbutamide plus $8 \mathrm{mmol} / 1 \mathrm{~K}^{+}$glucose induced additional inhibition of glucagon secretion, most of which occurred without accompanying changes in insulin or somatostatin release. Further evidence for insulin- and somatostatin-independent effects on glucagon release was obtained with the observation that CPA inhibition of the SERCA pump stimulated glucagon secretion without affecting basal secretion of insulin or somatostatin. Moreover, CPA prevented glucose inhibition of glucagon secretion. Indeed, during SERCA inhibition, $20 \mathrm{mmol} / 1$ glucose stimulated glucagon, insulin and somatostatin release in parallel. Apparently, paracrine interactions do not suffice to explain the observed alterations of glucagon secretion. Glucose inhibits glucagon secretion from clonal glucagonreleasing cells $[5,11,17]$, and studies of pancreatic islets and cells have provided additional evidence that glucose regulates glucagon release by a direct effect on the alpha cell $[5,8-10,12-17]$.

The $\mathrm{K}_{\text {ATP }}$ channel has a central function in glucosestimulated insulin release, transducing an increase in ATP into depolarisation with voltage-dependent influx of $\mathrm{Ca}^{2+}$ [37]. Paradoxically, the $\mathrm{K}_{\mathrm{ATP}}$ channel has also been proposed to mediate glucose inhibition of glucagon secretion by depolarising the alpha cell $[13,16]$. In this case, depolarisation is assumed to inactivate $\mathrm{Na}^{+}$-dependent action potentials and thereby inhibit secretion by preventing voltage-dependent $\mathrm{Ca}^{2+}$ influx $[13,16,31]$. The scenario predicts that closure of the $\mathrm{K}_{\mathrm{ATP}}$ channels should result in depolarisation and lowering of $\left[\mathrm{Ca}^{2+}\right]_{\mathrm{i}}$. We instead determined that the depolarisation obtained with tolbutamideinduced closure of the $\mathrm{K}_{\mathrm{ATP}}$ channels was associated with increase of $\left[\mathrm{Ca}^{2+}\right]_{\mathrm{i}}$ in $21 \%$ of previously silent alpha cells and in $80 \%$ of the cells with spontaneous $\left[\mathrm{Ca}^{2+}\right]_{\mathrm{i}}$ activity in $1 \mathrm{mmol} / \mathrm{l}$ glucose. Similar evidence has been obtained with rat alpha cells, which have much higher $\mathrm{K}_{\mathrm{ATP}}$ channel density [43] than mouse alpha cells [13, 44]. Accordingly, tolbutamide stimulates the electrical activity [43] and exocytosis of glucagon [45] in isolated rat alpha cells, and 


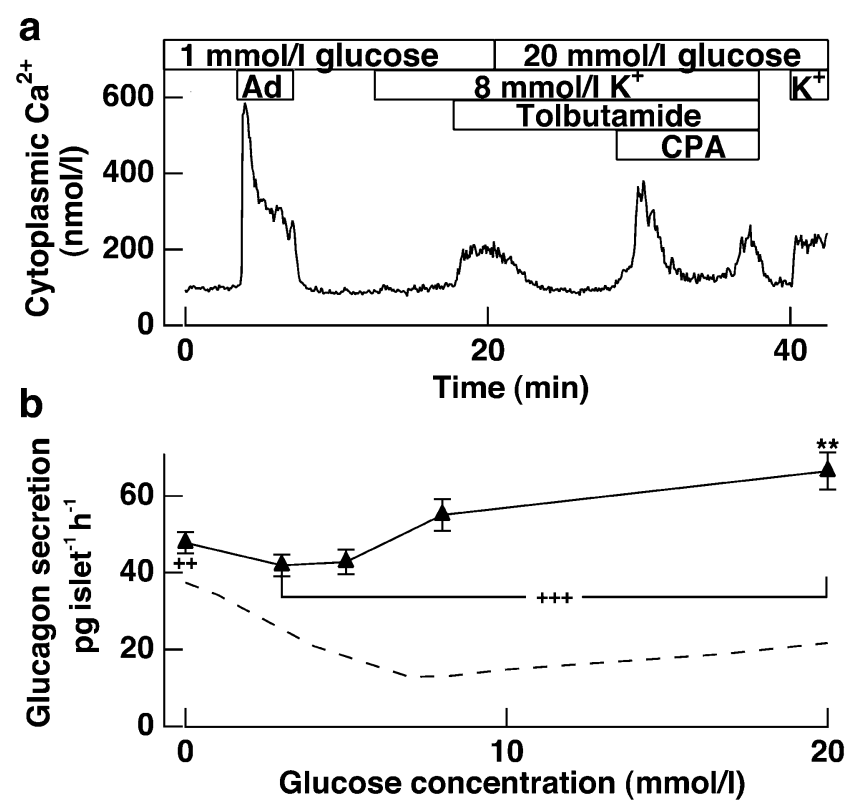

glucose was recently found to stimulate glucagon release from purified rat alpha cells [46]. Interestingly, two studies of $\mathrm{K}_{\text {ATP }}$ channel knockout mice support a stimulatory role of these channels in alpha cells. The most salient effect of knocking out the regulatory $\mathrm{K}_{\text {ATP }}$ channel subunit sulfonylurea receptor 1 is low glucagon secretion with absent
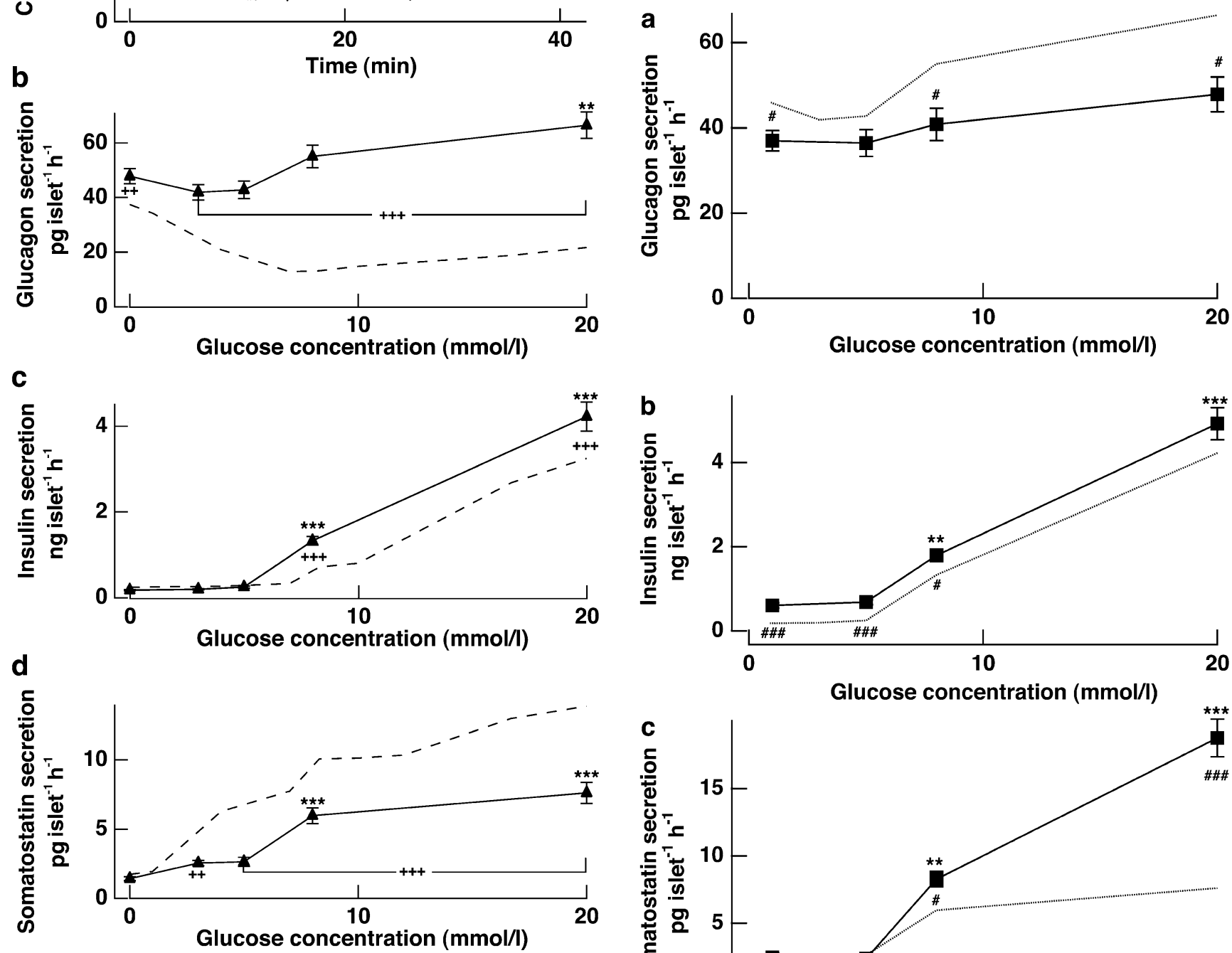

Fig. 5 Effects of the SERCA inhibitor CPA on $\left[\mathrm{Ca}^{2+}\right]_{\mathrm{i}}$ of an alpha cell and on glucagon, insulin and somatostatin secretion from mouse islets. a $\left[\mathrm{Ca}^{2+}\right]_{\mathrm{i}}$ was measured in an alpha cell loaded with the $\mathrm{Ca}^{2+}$ indicator fura-2. Glucose $(1$ or $20 \mathrm{mmol} / \mathrm{l})$, tolbutamide $(500 \mu \mathrm{mol} / \mathrm{l})$, $8 \mathrm{mmol} / \mathrm{l} \mathrm{K}{ }^{+}, 5 \mu \mathrm{mol} / 1$ adrenaline (Ad) and $50 \mu \mathrm{mol} / 1 \mathrm{CPA}$ were present as indicated. At the end of the experiment, the $\mathrm{K}^{+}$ concentration was raised to $30 \mathrm{mmol} / 1\left(\mathrm{~K}^{+}\right)$. Glucagon (b), insulin (c) and somatostatin (d) secretion were measured after $60 \mathrm{~min}$ incubation in the presence of $50 \mu \mathrm{mol} / \mathrm{l} \mathrm{CPA}$ and 0 to $20 \mathrm{mmol} / \mathrm{l}$ glucose (filled triangles, solid lines). Control secretion data in 1 to $20 \mathrm{mmol} / 1$ glucose alone from Fig. 1 are included for comparison (dashed lines). Data are presented as means \pm SEM of ten experiments. Double asterisks: $p<0.01$, triple asterisks: $p<0.001$ for the effect of glucose compared with the lowest concentration tested $(0 \mathrm{mmol} / \mathrm{l})$. Double plus signs: $p<0.01$, triple plus signs: $p<0.001$ for the effect of $50 \mu \mathrm{mol} / 1 \mathrm{CPA}$ compared with control. Brackets indicate observations with identical significance levels

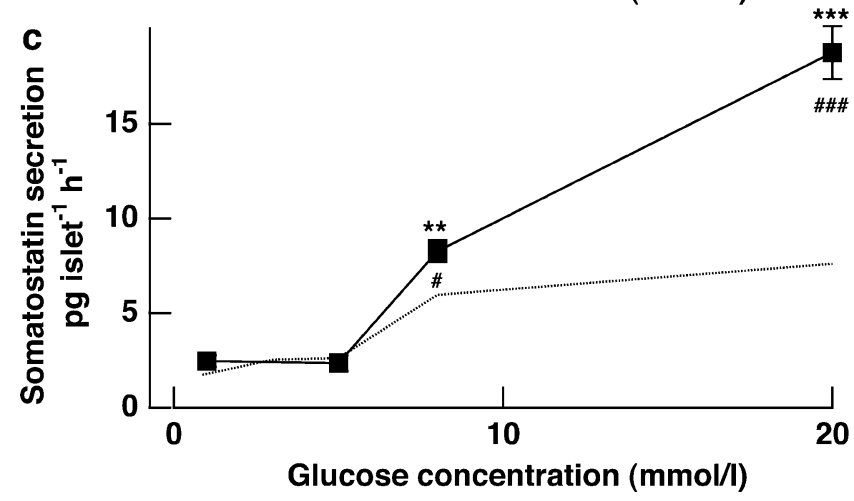

Fig. 6 Effects of the SERCA inhibitor CPA on glucagon, insulin and somatostatin secretion from mouse islets with closed $\mathrm{K}_{\mathrm{ATP}}$ channels. Glucagon (a), insulin (b) and somatostatin (c) secretion were measured after $60 \mathrm{~min}$ incubation in the presence of $50 \mu \mathrm{mol} / 1 \mathrm{CPA}$, $500 \mu \mathrm{mol} / 1$ tolbutamide plus $8 \mathrm{mmol} / 1 \mathrm{~K}^{+}$and 1 to $20 \mathrm{mmol} / 1$ glucose (filled squares, solid lines). Secretion data in the presence of CPA from Fig. 5 are included for comparison (dotted lines). Data are presented as means \pm SEM of eight experiments. Double asterisks: $p<0.01$, triple asterisks: $p<0.001$ for the effect of glucose compared with the lowest concentration tested $(1 \mathrm{mmol} / \mathrm{l})$. Number signs: $p<0.05$, triple number signs: $p<0.001$ for the effect of $50 \mu \mathrm{mol} / 1 \mathrm{CPA}$ and $500 \mu \mathrm{mol} / \mathrm{l}$ tolbutamide plus $8 \mathrm{mmol} / 1 \mathrm{~K}^{+}$compared with $50 \mu \mathrm{mol} / 1$ CPA 
[47] or diminished [48] stimulation in response to lowering of glucose.

We recently proposed that glucose regulates glucagon secretion by a $\mathrm{Ca}^{2+}$ store-operated mechanism [15]. This model explains both adrenergic stimulation and glucose inhibition of glucagon release. By releasing $\mathrm{Ca}^{2+}$ from the endoplasmic reticulum, adrenergic stimuli activate a depolarising store-operated influx of cations, which eventually triggers voltage-dependent $\mathrm{Ca}^{2+}$ influx and glucagon secretion. The role of glucose is to activate $\mathrm{Ca}^{2+}$ sequestration in the endoplasmic reticulum and shut off the stimulatory cascade. In the absence of voltage-dependent $\mathrm{Ca}^{2+}$ entry, activation of the store-operated pathway results in a modest rise of $\left[\mathrm{Ca}^{2+}\right]_{\mathrm{i}}$ in alpha cells [15]. The small store-operated current is sufficient to trigger voltagedependent $\mathrm{Ca}^{2+}$ influx because of the high input resistance [12] and the fact that the action potentials start at voltages as negative as $-60 \mathrm{mV}[13,39,43]$. In support of the involvement of a store-operated mechanism in the regulation of glucagon secretion, we observed that activation of the store-operated pathway by SERCA inhibition raised $\left[\mathrm{Ca}^{2+}\right]_{\mathrm{i}}$ and stimulated glucagon release from mouse islets without affecting the basal secretion of insulin or somatostatin. Moreover, SERCA inhibition abolished the $\left[\mathrm{Ca}^{2+}\right]^{-}$ lowering effect of glucose in isolated alpha cells and prevented glucose inhibition of glucagon secretion from mouse islets despite the fact that the sugar stimulated the release of insulin and somatostatin.

Although rat and mouse are closely related species, glucagon secretion from pancreatic alpha cells may be differently regulated. In isolated rat alpha cells with high $\mathrm{K}_{\text {ATP }}$ channel density [43] the direct effect of glucose seems to be stimulation of secretion and the inhibitory action may require release of paracrine islet factors [46]. In isolated mouse alpha cells with low $\mathrm{K}_{\text {ATP }}$ channel density $[13,44]$ the inhibitory effect of glucose dominated, although closure of the $\mathrm{K}_{\text {ATP }}$ channels themselves was modestly stimulatory. The data support the concept that glucose has a direct inhibitory effect on the alpha cell by suppressing a depolarising store-operated current. However, neither beta cell factors nor somatostatin seem to mediate glucose inhibition of glucagon secretion.

Acknowledgements This work was supported by grants from the Swedish Research Council (12X-6240), the Swedish Diabetes Association, the Carl Trygger foundation, Family Ernfors foundation, Albert Påhlsson's foundation, the Crafoord foundation and the Scandinavian Physiological Society. The authors thank H. Ortsäter for measuring the insulin content of the perifusate.

Duality of interest The authors have no duality of interest related to this publication.

\section{References}

1. Gerich JE, Charles A, Grodsky GM (1976) Regulation of pancreatic insulin and glucagon secretion. Annu Rev Physiol 38:353-388

2. Buchanan KD, McCarroll AM (1972) Abnormalities of glucagon metabolism in untreated diabetes mellitus. Lancet 300:1394-1395

3. Ohneda A, Watanabe K, Horigome K, Sakai T, Kai Y, Oikawa S (1978) Abnormal response of pancreatic glucagon to glycemic changes in diabetes mellitus. J Clin Endocrinol Metab 46:504-510

4. Mitrakou A, Kelley D, Veneman T et al (1990) Contribution of abnormal muscle and liver glucose metabolism to postprandial hyperglycemia in NIDDM. Diabetes 39:1381-1390

5. Salehi A, Vieira E, Gylfe E (2006) Paradoxical stimulation of glucagon secretion by high glucose concentrations. Diabetes $55: 2318-2323$

6. Cryer PE, Davis SN, Shamoon H (2003) Hypoglycemia in diabetes. Diabetes Care 26:1902-1912

7. Cryer PE (2002) Hypoglycaemia: the limiting factor in the glycaemic management of Type I and Type II diabetes. Diabetologia 45:937-948

8. Pipeleers DG, Schuit FC, Van Schravendijk CFH, Van de Winkel M (1985) Interplay of nutrients and hormones in the regulation of glucagon release. Endocrinology 117:817-823

9. Unger RH (1985) Glucagon physiology and pathophysiology in the light of new advances. Diabetologia 28:574-578

10. Johansson H, Gylfe E, Hellman B (1987) The actions of arginine and glucose on glucagon secretion are mediated by opposite effects on cytoplasmic $\mathrm{Ca}^{2+}$. Biochem Biophys Res Commun 147:309-314

11. Bode HP, Weber S, Fehmann HC, Göke B (1999) A nutrientregulated cytosolic calcium oscillator in endocrine pancreatic glucagon-secreting cells. Pflügers Arch 437:324-334

12. Barg S, Galvanovskis J, Göpel SO, Rorsman P, Eliasson L (2000) Tight coupling between electrical activity and exocytosis in mouse glucagon-secreting $\alpha$-cells. Diabetes 49:1500-1510

13. Göpel SO, Kanno T, Barg S, Weng XG, Gromada J, Rorsman P (2000) Regulation of glucagon secretion in mouse $\alpha$-cells by $\mathrm{K}_{\text {ATP }}$ channels and inactivation of TTX-sensitive $\mathrm{Na}^{+}$channels. J Physiol (Lond) 528:509-520

14. Hjortoe GM, Hagel GM, Terry BR, Thastrup O, Arkhammar PO (2004) Functional identification and monitoring of individual $\alpha$ and $\beta$ cells in cultured mouse islets of Langerhans. Acta Diabetol 41:185-193

15. Liu YJ, Vieira E, Gylfe E (2004) A store-operated mechanism determines the activity of the electrically excitable glucagonsecreting pancreatic $\alpha$-cell. Cell Calcium 35:357-365

16. Gromada J, Ma X, Hoy M et al (2004) ATP-sensitive $\mathrm{K}^{+}$channeldependent regulation of glucagon release and electrical activity by glucose in wild-type and SUR $1^{-/}$mouse $\alpha$-cells. Diabetes 53 (Suppl 3):S181-S189

17. Ravier MA, Rutter GA (2005) Glucose or insulin, but not zinc ions, inhibit glucagon secretion from mouse pancreatic $\alpha$-cells. Diabetes 54:1789-1797

18. Starke A, Imamura T, Unger RH (1987) Relationship of glucagon suppression by insulin and somatostatin to the ambient glucose concentration. J Clin Invest 79:20-24

19. Östenson CG (1979) Regulation of glucagon release: effects of insulin on the pancreatic $\mathrm{A}_{2}$-cell of the guinea pig. Diabetologia $17: 325-330$

20. Berts A, Ball A, Gylfe E, Hellman B (1996) Suppression of $\mathrm{Ca}^{2+}$ oscillations in glucagon-producing $\alpha_{2}$-cells by insulin/glucagon and amino acids. Biochim Biophys Acta 1310:212-216 
21. Diao J, Asghar Z, Chan CB, Wheeler MB (2005) Glucoseregulated glucagon secretion requires insulin receptor expression in pancreatic $\alpha$-cells. J Biol Chem 280:33487-33496

22. Xu E, Kumar M, Zhang $Y$ et al (2006) Intra-islet insulin suppresses glucagon release via $\mathrm{GABA}-\mathrm{GABA}_{\mathrm{A}}$ receptor system. Cell Metabolism 3:47-58

23. Rorsman P, Berggren PO, Bokvist K et al (1989) Glucoseinhibition of glucagon secretion involves activation of $\mathrm{GABA}_{\mathrm{A}^{-}}$ receptor chloride channels. Nature 341:233-236

24. Wendt A, Birnir B, Buschard K et al (2004) Glucose inhibition of glucagon secretion from rat $\alpha$-cells is mediated by GABA released from neighboring $\beta$-cells. Diabetes 53:1038-1045

25. Ishihara $\mathrm{H}$, Maechler P, Gjinovci A, Herrera PL, Wollheim CB (2003) Islet $\beta$-cell secretion determines glucagon release from neighbouring $\alpha$-cells. Nat Cell Biol 5:330-335

26. Franklin I, Gromada J, Gjinovci A, Theander S, Wollheim CB (2005) $\beta$-cell secretory products activate $\alpha$-cell ATP-dependent potassium channels to inhibit glucagon release. Diabetes 54:1808 1815

27. Cejvan K, Coy DH, Efendic S (2003) Intra-islet somatostatin regulates glucagon release via type 2 somatostatin receptors in rats. Diabetes 52:1176-1181

28. Miki T, Liss B, Minami K et al (2001) ATP-sensitive $\mathrm{K}^{+}$channels in the hypothalamus are essential for the maintenance of glucose homeostasis. Nat Neurosci 4:507-512

29. Liu YJ, Hellman B, Gylfe E (1999) $\mathrm{Ca}^{2+}$ signaling in mouse pancreatic polypeptide cells. Endocrinology 140:5524-5529

30. Bergsten P, Grapengiesser E, Gylfe E, Tengholm A, Hellman B (1994) Synchronous oscillations of cytoplasmic $\mathrm{Ca}^{2+}$ and insulin release in glucose-stimulated pancreatic islets. J Biol Chem 269:8749-8753

31. Göpel S, Zhang Q, Eliasson L et al (2004) Capacitance measurements of exocytosis in mouse pancreatic $\alpha$-, $\beta$ - and $\delta$-cells within intact islets of Langerhans. J Physiol 556:711-726

32. Johansson H, Gylfe E, Hellman B (1989) Cyclic AMP raises cytoplasmic calcium in pancreatic $\alpha_{2}$-cells by mobilizing calcium incorporated in response to glucose. Cell Calcium 10: 205-211

33. Berts A, Ball A, Dryselius S, Gylfe E, Hellman B (1996) Glucose stimulation of somatostatin-producing islet cells involves oscillatory $\mathrm{Ca}^{2+}$ signalling. Endocrinology 137:693-697

34. Panagiotidis G, Salehi AA, Westermark P, Lundquist I (1992) Homologous islet amyloid polypeptide: effects on plasma levels of glucagon, insulin and glucose in the mouse. Diabetes Res Clin Pract 18:167-171
35. Etzrodt H, Rosenthal J, Schroder KE, Pfeiffer EF (1983) Radioimmunoassay of somatostatin in human plasma. Clin Chim Acta 133:241-251

36. Braun M, Wendt A, Birnir B et al (2004) Regulated exocytosis of GABA-containing synaptic-like microvesicles in pancreatic $\beta$ cells. J Gen Physiol 123:191-204

37. Ashcroft FM, Rorsman P (1990) ATP-sensitive $\mathrm{K}^{+}$channels: a link between B-cell metabolism and insulin secretion. Biochem Soc Trans 18:109-111

38. Göpel SO, Kanno T, Barg S, Rorsman P (2000) Patch-clamp characterisation of somatostatin-secreting $\delta$-cells in intact mouse pancreatic islets. J Physiol (Lond) 528:497-507

39. Rorsman P, Hellman B (1988) Voltage-activated currents in guinea pig pancreatic $\alpha_{2}$ cells. Evidence for $\mathrm{Ca}^{2+}$-dependent action potentials. J Gen Physiol 91:223-242

40. Gromada J, Bokvist K, Ding WG et al (1997) Adrenaline stimulates glucagon secretion in pancreatic A-cells by increasing the $\mathrm{Ca}^{2+}$ current and the number of granules close to the L-type $\mathrm{Ca}^{2+}$ channels. J Gen Physiol 110:217-228

41. Gerich JE, Charles A, Grodsky GM (1974) Characterization of the effects of arginine and glucose on glucagon and insulin release from the perfused rat pancreas. J Clin Invest 54:833-841

42. Gylfe E (1990) How secretion is inhibited. Nature 344:300

43. Bokvist K, Olsen HL, Høy M et al (1999) Characterisation of sulphonylurea and ATP-regulated $\mathrm{K}^{+}$channels in rat pancreatic Acells. Pflügers Arch 438:428-436

44. Quesada I, Nadal A, Soria B (1999) Different effects of tolbutamide and diazoxide in $\alpha$-, $\beta$ - and $\delta$-cells within intact islets of Langerhans. Diabetes 48:2390-2397

45. Høy M, Olsen HL, Bokvist K et al (2000) Tolbutamide stimulates exocytosis of glucagon by inhibition of a mitochondrial-like ATPsensitive $\mathrm{K}^{+}\left(\mathrm{K}_{\text {ATP }}\right)$ conductance in rat pancreatic A-cells. J Physiol (Lond) 527:109-120

46. Olsen HL, Theander S, Bokvist K, Buschard K, Wollheim CB, Gromada J (2005) Glucose stimulates glucagon release in single rat $\alpha$-cells by mechanisms that mirror the stimulus-secretion coupling in $\beta$-cells. Endocrinology 146:4861-4870

47. Shiota C, Rocheleau JV, Shiota M, Piston DW, Magnuson MA (2005) Impaired glucagon secretory responses in mice lacking the type 1 sulfonylurea receptor. Am J Physiol Endocrinol Metab 289: E570-E577

48. Muñoz A, Hu M, Hussain K, Bryan J, Aguilar-Bryan L, Rajan AS (2005) Regulation of glucagon secretion at low glucose concentrations: evidence for adenosine triphosphate-sensitive potassium channel involvement. Endocrinology 146:5514-5521 